\title{
Current state and prospects of wind energy development in Ukraine
}

\author{
Yuriy Pantsyr ${ }^{1, *}$, Ihor Garasymchuk ${ }^{1}$, Vasyl Duganets ${ }^{1}$, Mariia Melnyk ${ }^{2}$, and Oksana \\ Yurchenko ${ }^{2}$ \\ ${ }^{1}$ State Agrarian and Engineering University in Podilia, 32300 Kamianets-Podilskyi, Ukraine \\ ${ }^{2}$ Sumy National Agrarian University, 40021 Sumy, Ukraine
}

\begin{abstract}
The analysis of the development of alternative energy sources in the developed countries of the world was carried out, as well as the strategy of the implementation of wind energy in Ukraine was considered. The emphasis was on the design and operation of wind power units and the investment of investment funds in modernizing existing wind power plants and building new ones. The most attractive regions for wind power use in Ukraine was presented. The advantages and disadvantages of using nontraditional energy sources and the features of operation of wind power plants were substantiated.
\end{abstract}

\section{Introduction}

Despite the prospects for the development of the world economy and business, in recent years the demand for electricity has been growing steadily and the struggle for extracting affordable and cheaper energy sources, which is essential for its use in various sectors of the national economy, remains a pressing issue.

Existing traditional energy sources today are not able to fully provide human energy with the cheap energy. In addition, taking into account the growing depletion of mineral resources, society requires a sharp increase in the efficiency of the use of natural resources, the adoption of new non-traditional solutions, capable of solving the shortage of power capacities in the shortest possible time and with minimal cost. The acute problem of using traditional energy sources necessitates the development of energy through the introduction of energy efficient and environmentally friendly technologies.

World science is looking for new and improved existing technologies, bringing them to an economically efficient level and expanding areas of use.

An important criterion for the sustainable development of the world's energy industry has recently been the so-called alternative, non-traditional and renewable energy sources. As soon as possible, they can change the structure of production and consumption of energy, and create environmentally friendly energy systems.

One of these sources is wind power. This is an alternative energy industry specializing in converting kinetic energy into electric energy. It is a high-tech, economical and environmentally-friendly energy sector based on the use of a renewable energy source to

\footnotetext{
*Corresponding author: pro-gp@pdatu.edu.ua
} 
solve one of the most critical human problems - the original struggle for energy, and at the same time reducing the negative impact on the environment. Over the past 10-15 years, its development has intensified in many countries around the world.

The prospect of wind energy as a business contributes, besides the high return on capital costs, to the enormous potential energy resources of wind flow in certain areas.

Since wind power is based on the transformation of the kinetic energy of air masses into the atmosphere into electric, mechanical, thermal or other energy-friendly types of energy, modern scientists increasingly focus their efforts on solving problems associated with the widespread use of wind energy. Wind energy is well received throughout the world as an inexhaustible clean green energy. The total wind energy potential of the Earth is enormous: according to authoritative expert estimates, it is about $1200 \mathrm{TWh}$. However, the real use of this potential encounters a number of difficulties due to the unevenness of its distribution in different parts of the globe, as well as large losses in its transformation into other types of energy. Wind energy has long been a key energy sector in Europe. For many years, it has been ranked first in the EU in terms of the net increase in generating capacity.

The Global Wind Energy Council (GWEC) provides information that over the past years, more than $54.6 \mathrm{GW}$ of wind power capacities has been built in the world. At present, the installed capacity of objects that operate on the basis of wind energy, reaches $486.7 \mathrm{GW}$ $[1]$.

Before considering the strategy of wind energy in Ukraine, briefly consider the global and European achievements in the development of wind energy.

The main countries of the world's wind power industry are China, the United States, Germany and India, which account for $72 \%$ of the world's wind power output. China has achieved a significant total power of wind power and has crossed today the mark of 100 GW.

In the United States, wind power facilities with a total capacity of over $8.2 \mathrm{GW}$ were built. This is not a record but rather significant indicator. In the EU, more than $12.5 \mathrm{GW}$ of power was put into operation. Here since 2012 there is approximately the same level of annual connections of new wind energy objects [2].

In 2017, about $7 \mathrm{GW}$ of wind power plants have been put into operation in Germany, a record indicator for all history. Such a significant increase is attributed to the fact that the energy authorities sought to complete long-approved projects by the end of the year in order to obtain appropriate "green tariffs." Today, new projects in wind power are implemented only on a competitive basis. In 2017, the German wind energy output for the first time in the year exceeded 100 billion $\mathrm{kWh}$.

In subsequent years, such a rapid development of wind energy is not expected, as the legislation limits the annual growth of wind power plants - no more than $2800 \mathrm{MW}$ per year (in 2020 - $2900 \mathrm{MW}$ ). The purpose of offshore energy development - $6500 \mathrm{MW}$ of installed capacity by 2020 and 15 GW - 2030

Despite these restrictions, it is already clear today that the immediate targets for REE, recorded in EEG for 2025, will be overfulfilled (according to the law, in 2025, 40-45\% of electricity consumption should be provided by renewable energy generation facilities energy sources). And most interestingly, about half of the wind power plants in Germany are owned by private individuals, farmers or communes [3]. 


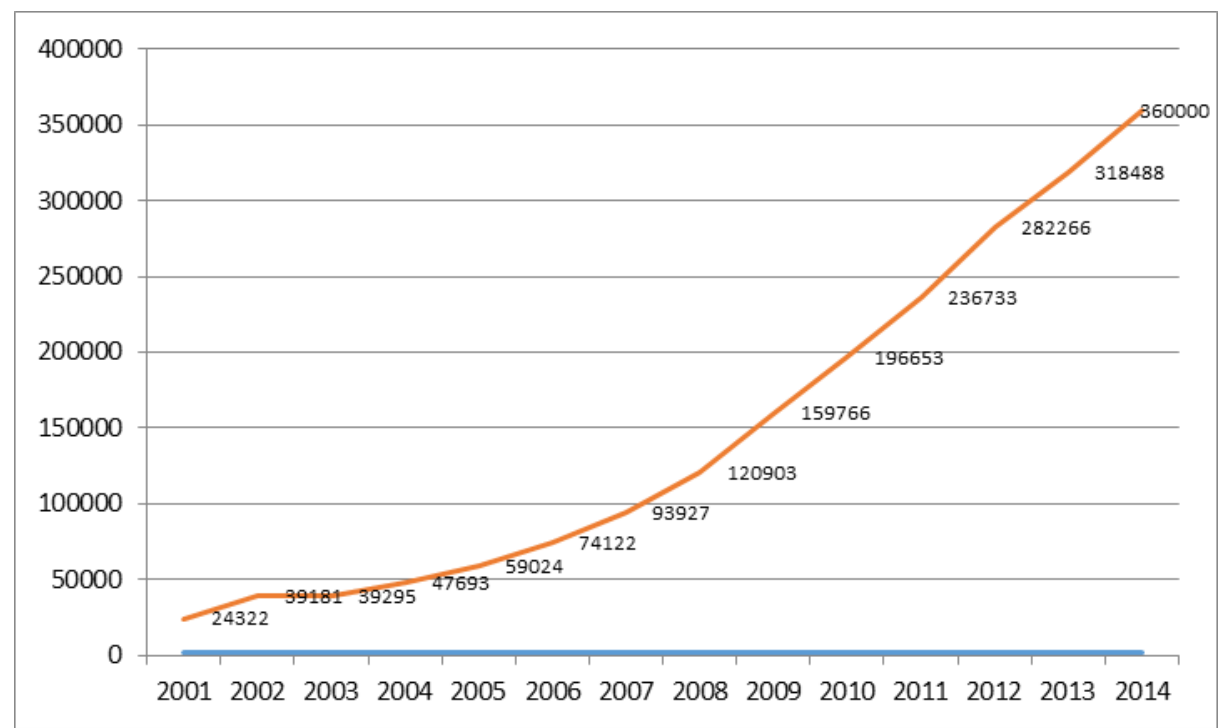

Fig. 1. Wind turbines installed, MW

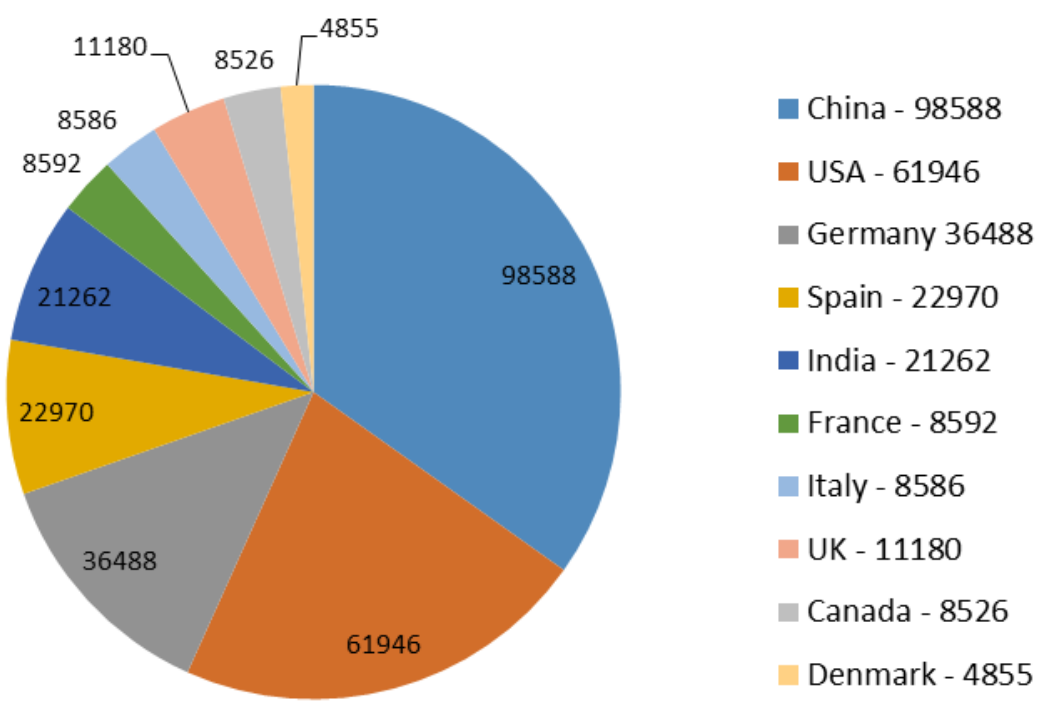

Fig. 2. TOP - 10 countries by number of wind power production in 2014, MW

India has set a national record of $3612 \mathrm{MW}$, GWEC reports, and the total power of wind power in the country reached $28.7 \mathrm{GW}$ (the world's fourth wind power company). By 2022 it is planned to reach $60 \mathrm{GW}$ of wind power.

Brazil has a high rate of wind energy growth. In Brazil, 2014 MW was built - the world's fifth largest growth index, with the installed power of wind power exceeding 10 GW. Wind energy can positively influence the power industry in this country and replace gas, nuclear, coal and hydroelectric power plants. The Brazilian authorities estimated the wind energy at a price of about 5 cents per kilowatt-hour. Observers are worried about lower profitability of wind farms, and meanwhile, the wind energy compensates producing hydroelectric power for Brazil, filling the gap at the end of the rainy season. 
It is also worth paying attention to Turkey, where $1387 \mathrm{MW}$ of capacity was connected for one year. Africa last year failed to boast large volumes of new wind power, only South Africa built $418 \mathrm{MW}$. At the same time, more than $800 \mathrm{MW}$ of wind power plants are under construction in Morocco, which will be put into operation already in the current year. New wind power markets are emerging in Asia, Africa and Latin America [1].

Specifically, the Canadian government is implementing a wind power policy, as it implements this project in selected provinces. In general, the power of wind power plants in Canada is more than $5.5 \mathrm{GW}$. The wind energy program is being implemented in the provinces of Ontario and Nova Scotia, where special incentives are applied to investors' communities.

According to the latest estimates, in Denmark, the amount of wind power has reached $43.6 \%$ of the total electricity consumption, and by 2020 this figure is planned to increase to $50 \%$. The Danes are very clever integrating the energy of the wind into their energy system. In one of the municipalities, electricity is supplied more than $100 \%$ from renewable sources, and the entire surplus is spent on heating. Despite the cold climate in Denmark, it is possible to maintain the prosperity and image of an industrially developed country [4].

Wind energy has long been a key energy sector in Europe. For many years, it has been ranked first in the EU in terms of the net increase in generating capacity.

In many developed countries there are state programs for the development of renewable energy sources, including wind power. The most effective in terms of increasing the total capacity of wind farms are programs from countries in Europe, China, India, the USA, Canada. These programs fund scientific, technical, energy, environmental, social and educational programs. Generators of renewable energy projects in Europe are research centers (RISO, SERI (now NREL), Sandia ecn, TNO, NLR, FFA, D (FV) LR, CIEMAT, etc.), universities and interested companies.

Ukraine is capable of effectively using wind energy in separate zones at an average annual wind speed of more than 4-5 m/ s. Such speeds are sufficient for the construction of wind power plants.

The Institute of Renewable Energy of the National Academy of Sciences of Ukraine is a map of the wind energy potential of our country. The most attractive regions for using wind energy are the Black Sea and Azov Sea, mountainous regions of the temporarily occupied Crimea, the Carpathian Mountains, Odessa, Kherson and Mykolaiv regions (Fig. 3) [2].

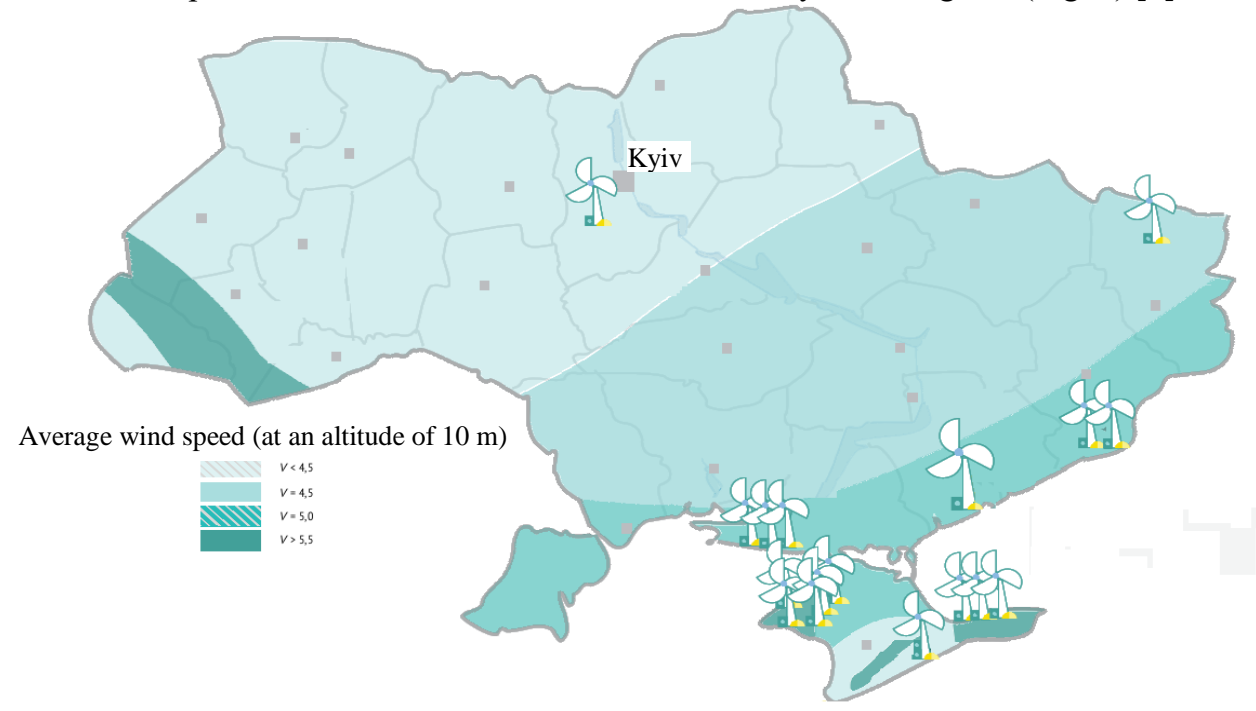

Fig.3. General characteristics of wind streams on the territory of Ukraine. 
The development of wind energy in Ukraine began in 1996 with the construction of Novoazovskaya and later Truskavets wind power plants. By 2015, 14 wind farms have been built in Ukraine, equipped with both imported and own wind generators. The production of Ukrainian wind turbines is set up on the "Pivdenmash" in the Dnipro, as well as by the joint Ukrainian-German company "LLC Fuhrlaender Wind Technology" in Kramatorsk. However, due to the annexation of the Crimea and prolonged hostilities in the Donbass, the introduction of new capacity of wind power plants in our country since 2015 has slowed down by almost 8 times compared with 2014. In addition, military actions have stopped investors' interest in investing in large projects of Ukraine.

To date, the installed capacity of wind power plants throughout Ukraine (including the Crimea) is $514 \mathrm{MW}$, of which $426 \mathrm{MW}$ on the mainland, and 87.7 - in the Crimea. In addition, there are 4 wind power plants with a total capacity of about $140 \mathrm{MW}$ located on Donbass's uncontrolled Ukrainian territory. Currently operating in Ukraine there is only one modern $25 \mathrm{MW}$ power station, which is located in the Crimea and belongs to the "Windy Parks of Ukraine". The remaining stations do not work due to lack of service and maintenance personnel.

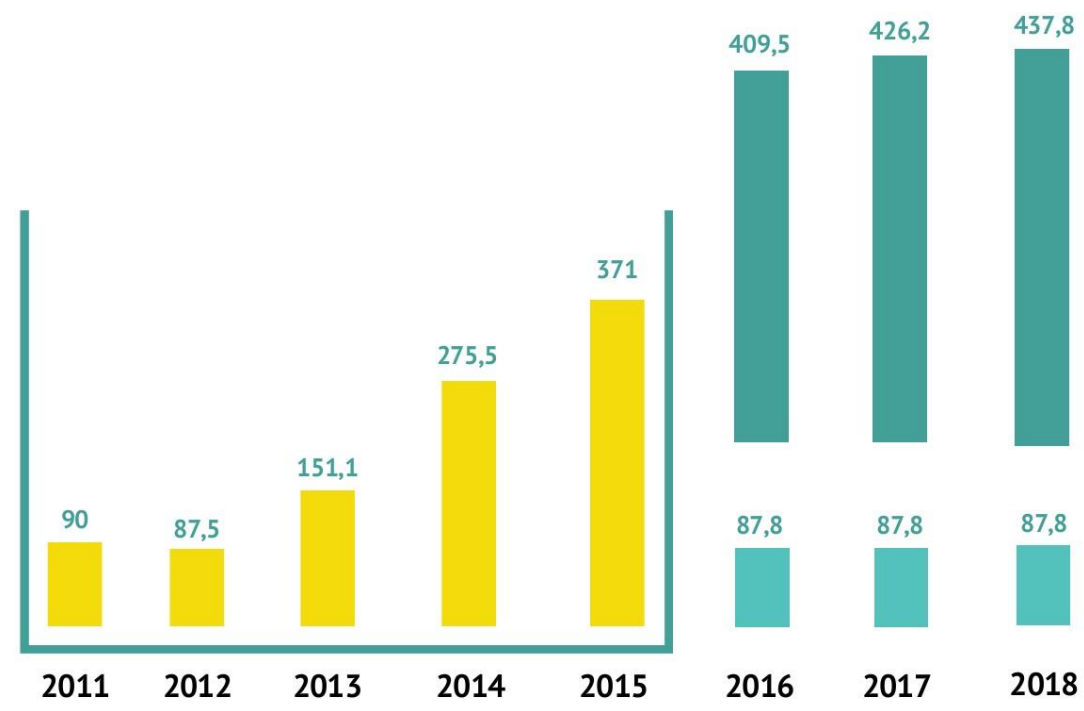

Fig. 4. Installed power of wind power plants, $\mathrm{mW}$.

At the same time, Ukraine has its own positive sides.

Over the past 3 years in the Kherson region, thanks to consistent government actions and improvements to the legislative framework, around 700 million euros are involved in Ukrainian "green" projects. Almost 400 million euros have been invested in the introduction of $1670 \mathrm{MW}$ of new thermal capacity using alternative energy sources. About 300 million euros were directed by the business to install 278 MW of renewable energy facilities.

As of September 1, 2018, the capacity of alternative energy facilities operating on a green tariff in the Kherson region exceeded $105 \mathrm{MW}$. Of these, almost $40 \mathrm{MW}$ were put into operation in 2017. In particular, this year the Trifanovskaya SES of the company DTEK (Trifanovka Energii LLC) with a capacity of $10 \mathrm{MW}$, SES Belozerka (LLC "Renji Bershad") with a capacity of $11 \mathrm{MW}$ and SES Nikolaevka ("Renji Trostyanets") with a capacity of almost $6 \mathrm{MW}$ were launched. 
As part of the investment forum, the opening ceremony of the first stage of Novotroitskaya wind power plant of Windcraft Ukraine took place. At present, the first 12 wind turbines with a capacity of $43.2 \mathrm{MW}$ have started to work. In the future, the power of the wind farm should increase to $140 \mathrm{MW}$. Windcraft Ukraine already operates three wind power plants in Kherson region with a total capacity of $70 \mathrm{MW}$ [5].

The Chinese company TBEA (Tebian Electric Apparatus) plans to build and commission a 2019 wind power plant in the Mykolaiv region. The project will cost $\$ 500$ million and involves the construction of a $500 \mathrm{MW}$ station [6].

The founder of Atlas Global Energy Ennis Enis Fakioglu declared a Memorandum of Cooperation on the construction of a modern wind power plant in the Lviv region of Skolivshchyna. The capacity of the future wind farm at the first stage of the project will be $20 \mathrm{MW}$, and in the long term the installation of wind turbines is considered at least $50 \mathrm{MW}$. In the meantime, the design and estimate documentation for the construction of the wind power plant, as well as other necessary documents, is underway, and in the year 2018 the first "windmills" are planned. The parties agreed to work out a road map for the implementation of this alternative energy project in the Skolivshchyna.

Implementation of the project "Old Sambir-1", the most powerful wind farm (13.2 MW) in the territory of the Ukrainian Carpathians, jointly with the European Bank for Reconstruction and Development and the World Bank's Clean Technology Fund. The cost of the project is \$20.5 million. The first stage of the "Old Sambir-1" wind power plant is expected to produce 19.46 million $\mathrm{kWh}$ a year of electricity, while the return to the UES of Ukraine is estimated at 18.68 million $\mathrm{kWh}$. In the first stage, the VES "Old Sambir-1" installed two wind turbines of the "Vestas" type V-112-3.3, with a rated power of 3.3 MW each. From a technological point of view, it is the most advanced turbine. The height of the wind turbine tower reaches $119 \mathrm{~m}$, the length of the blade is $56 \mathrm{~m}$. The estimated lifetime is 20 years [7].

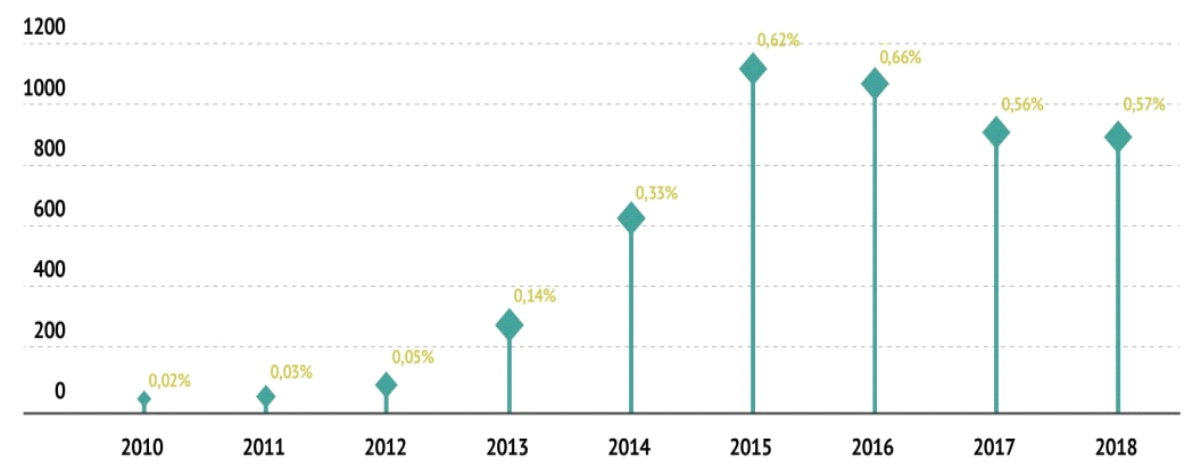

Fig. 5. Electricity production by wind power plants in Ukraine. Share in total electricity production, Million kWh

With regard to the benefits of wind energy, through which many countries of the world began to introduce it as a renewable energy source, the energy of the wind is economical. Wind based land use is one of the cheapest sources of energy available today.

Thanks to the wind energy, new jobs are created. More than 100,000 people were employed in the US wind power sector in 2016, and the US Labor Statistics Bureau called wind turbine technology the fastest-growing American work of the decade. According to the Wind Vision report, the wind can support more than 600,000 jobs in production, 
installation, maintenance and support services by 2050. Wind contributes to the growth of industry in the United States and its competitiveness.

Wind turbines do not produce atmospheric emissions that cause acid rain, smog or greenhouse gases. The wind is an internal source of energy. Wind resources are rich and inexhaustible.

The problem with wind energy is competition with conventional sources of cost-based generation. Depending on how vigorous the wind is, the wind power plant may not be competitively priced. Despite the fact that the cost of wind energy has fallen sharply over the past 10 years, technology requires higher initial investment than generators working on fossil fuels [8].

Good wind areas are often located in remote locations far from cities where electricity is needed. Power lines should be built to bring electricity from a wind power plant to the city. However, the construction of several already proposed transmission lines can significantly reduce the cost of expansion of wind energy.

The development of wind resources may not be the most advantageous use of land. An area suitable for installing wind turbines should compete with alternative land uses that can be more highly valued than electricity generation. Turbines can cause noise and aesthetic pollution. Although wind power plants produce relatively little environmental impact compared to conventional power plants, there is concern about the noise generated by turbine blades and visual effects on the landscape.

The turbine blades can damage local wildlife. Birds die, falling into the rotating turbine blades. Most of these problems have been resolved or significantly reduced thanks to the technological development and proper placement of wind turbines.

An important feature of wind energy is the inappropriateness of connecting wind power plants (VEU) to a single power system, since such a connection increases the risks of destabilization of the unified energy system (UES) [9].

Since wind power is sold at a fixed price over a long period of time (for example, over 20 years) and wind power is free, wind energy reduces uncertainty in the price associated with adding fuel costs to traditional energy sources [10].

The positives and negatives of wind energy still remain the subject of heated debate. There are two main arguments against wind energy: it is more expensive to produce electricity using wind than electricity from conventional sources such as nuclear and thermal energy. This means that subsidate of a producing wind power should be provided in the form of preferential tariff rates. The wind power is unstable because the winds are unpredictable and uncontrolled. This can lead to large fluctuations in the output and even stopping of wind turbines. However, to solve the problem of fragmentation of renewable energy sources, network operators associated with other sources such as solar energy [11] are used. Different variants of improvement of technology of installation of wind turbines are considered. At present, wind turbines are tied to the seabed at a depth of no more than 30 meters. Studies and tests are carried out on artificial islands and wind turbines on floating bases, fixed at a depth of 60 meters. To reduce investment costs, researchers are also exploring the potential use of existing offshore oil platforms, which are coming to an end with their useful life, with significant potential. Currently, 200 wind turbines are being built at the Beatrice oilfield, at a depth of 45 meters. Each turbine will be equipped with 60 meter blades constructed to withstand the winds of the North Sea.

With the assistance of the national government of China, wind energy and related technology are developing rapidly. According to data for August 2017, $169 \mathrm{GW}$ of wind power stations were operating in China, which is about $34 \%$ of wind power worldwide. China ranks first in the world in terms of installed wind power plants [12]. Wind energy not only affects the local power supply and reduces environmental pollution, but also contributes to the development of the economy and the increase of new job creation 
opportunities. At present, wind energy technology includes increased autonomous power, changes in the blade, tower height growth, direct drive technology and hybrid drive, monitoring technology, which continue to improving [13].

Use of renewable energy as a replacement normal fossil fuels are characterized by cleanliness, lack of pollution, reversible distribution, comfort. All this stimulates the strategy of energy development [14]. The development of renewable energy sources may change the structure of production and consumption of energy, create environmentally friendly energy systems that are aimed at sustainable development, which is the best choice for future energy development [15, 17-19].

The main features of wind power plants (WES) are:

- parallel work with the network. In this case, the electricity produced by the wind farm must meet the requirements of the quality of electrical energy in the network. The network, in turn, should be able to accept power from wind power (transmission capacity of transmission lines, the availability of appropriate electricity meters, etc.) and respond in a timely manner to changes in its quantity;

- stand-alone wind power plant. For such work, the wind power system requires the installation of storage batteries that will accumulate the electric energy produced by wind generators under favorable weather conditions. The presence of batteries greatly increases the total cost of the system. Therefore, for the final decision to be made, it is necessary to conduct technical and economic calculations. Installation of autonomous wind power is possible in conjunction with photovoltaic modules;

- direct transformation of electric energy into heat. The electric energy produced by wind power plants is converted into heat by heating the volume of water with electric elements. That is, the battery is warm water. Such a scheme can be used for preliminary heating of water in the system of hot water supply [16].

\section{Summary}

The development of alternative energy sources is part of the anti-crisis policy. Despite the economic downturn, in recent years the world's energy sector has grown rapidly due to the development of investment projects in order to attract additional investments in this industry, as well as the introduction of promising technological innovations.

The main disadvantage of wind energy is the instability and irregularity of the wind flow. Also important is the question of the economic efficiency of wind power.

Wind power plants are economically and energetically more beneficial than thermal or atomic in terms of the use of fossil fuels.

The wind energy is inexhaustible. It is well received throughout the world as an inexhaustible, environmentally friendly "green" energy. Taking into account the prospects for the development of wind energy, the number of it will increase every year.

\section{References}

1. Results of development of world wind energy in 2016. [Electronic resource] // RenEn Renewable energy (2017). URL: http://renen.en/global-wind-energy-2017-statistics/\# (Date of reference: 24.11.2018).

2. Wind power | State Energy Efficiency of Ukraine URL: http://saee.gov.ua/uk/ae/windenergy (Date of reference: 08.02.2019).

3. V. Sidorovich In 2017, about $7 \mathrm{GW}$ of wind power plants were introduced in Germany URL: http://renen.ru/in-2017-about-7-gw-of-wind-power-stations-were-installed-ingermany/ (Date of reference: 08/02/2019). 
4. Yu. Krasilnikova Denmark set a record in wind energy in 2017. URL: https://hightechfm/2018/01/06/denmarksenergy (Date of reference: 08/02/2019).

5. Twelve wind generators were launched in the Kherson region. http://abcnews.com.ua/en/news/v-khersonskoi-oblosti-zapustili-dvenadtsatvetrogeneratorov (Date of reference: 08/02/2019).

6. The Chinese want to build the most powerful wind power plant in Eastern Europe in Ukraine. http://abcnews.com.ua/en/news/kitaitsy-khotiat-postroit-v-ukrainie-moshchnieishuiu-vietrianuiu-eliektrostantsiiu-v-vostochnoi-ievropie

7. Launch of the first stage of the VES "Old Sambir-1". http://abcnews.com.ua/en/news/v-karpatakh-zarabotaiet-vietroeliektro-stantsiia-starii$\underline{\text { sambir-1 }}$

8. V. Beley, E. Khartsfeld, Ya. Pyhotsky Modern wind energy: trends of development, problems and variants of their solution. Industrial power engineering. No. 8. P. 56-61. (2014)

9. A.S. Tarasov Possibilities of wind energy development as an alternative source of energy in Russia. «Technical sciences - from theory to practice»: materials of the XXXII international correspondence scientific and practical conference No 3 (28) March 2014. p. 35-41. (Novosibirsk: SibAk, 2014)

10. A.S. Tarasov, V.F. Kalinin On the prospects of wind energy in. New word in science: prospects for development - Collection of materials of the international scientific and practical conference. p. 241-242. (Cheboksary, 2014)

11. V.G. Nikolayev, S.V. Hanag, E.M. Perminov Status and prospects of development of world and fatherland wind power engineering. Part 1. World wind power. Library of Electrical Engineering, supplement to the magazine"Energetik". Issue 8 (164). 124 p. (Moskow, NTF Energoprojekt ", 2012)

12. V.I. Salygin, I.A. Guliyev, M.I. Ryabova Problems and Prospects for the Development of the Renewable Energy Sector in China. Bulletin of the Moscow State Institute of Molecular Biology. - 2015. - No. 4 (43). (2015)

13. M. Bilgili, A. Ozbek, B.Sahin An over view of renewable electric power capacity and progress in new technologies in the world. Renewable and Sustainable Energy Reviews. Vol. 49. - P. 323-334. (2015)

14. Wu Z., Wan Yiru, He Chuan, Yu Jianhui, Zhou Hao Development Status of China's Renewable Energy Power Generation. Conference Paper. - P. 3-5. (2009)

15. Liao C. H. Ou H. H., Lo S. L. Chiueh P. T., and Yua Y. H. A challenging approach for renewable energy market development. Renewable and Sustainable Energy Reviews. Vol. 15. P. 87 - 93. (2011)

16. Pantsyr, Y., Garasymchuk, I., Hutsol, T., Gordiychuk, I.: Energy Parameters' Calculation of a Hybrid Heat Supply System for a Private House in the Conditions of Western Part of Ukraine. Renewable Energy Sources: Engineering, Technology, Innovation: ICORES 2017, 765-780, (2018). DOI 10.1007/978-3-319-72371-6_75

17. S. Yermakov, T. Hutsol, S. Slobodian, S. Komarnitskyi, M. Tysh Possibility of using automation tools for planting of the energy willow cuttings. Renewable Energy Sources: Engineering, Technology, Innovation. ICORES 2018 (to be published)

18. S. Yermakov, T. Hutsol, O. Ovcharuk, I. Kolosiuk Mathematic simulation of cutting unloading from the bunker. Independent journal of management \& amp; production (IJM\&P). Pp. 758-777 (2019)

19. T. Hutsol, S. Yermakov, Ju. Firman, V. Duganets, A. Bodnar Analysis of technical solutions of planting machines, which can be used in planting energy willow. Renewable Energy Sources: Engineering, Technology, Innovation. ICORES 2018 (to be published) 